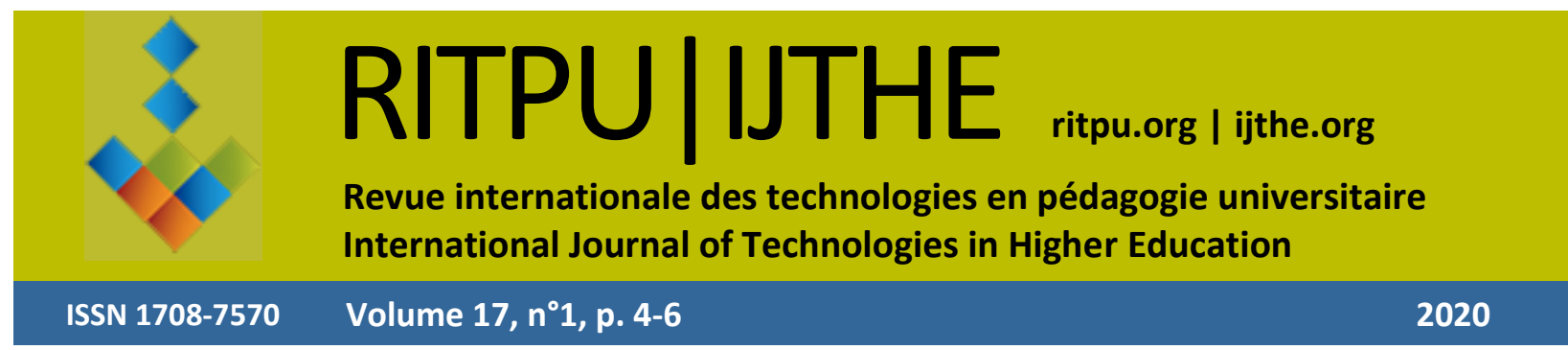

\title{
Digital Action Plan for Education and Higher Education: The Driving Force Behind a Plethora of College Initiatives. Introduction to the Special Issue
}

Thierry KARSENTI thierry.karsenti@umontreal.ca

Michel LEPAGE michel.lepage@umontreal.ca

Université de Montréal

https://doi.org/10.18162/ritpu-2020-v17n1-02

On May 30, 2018, the government of Quebec unveiled its Digital Action Plan for Education and Higher Education (Ministère de l'Éducation et de l'Enseignement supérieur [MEES], 2018). More specifically, this plan was created because the shift to digital was - and remains - a unique opportunity for the development and growth of Quebec. This digital action plan was developed in the hopes that digital technology will permeate a range of development initiatives in various fields, especially in education.

As the fourth major industrial revolution after mechanization, electrification, and automation (Cristol, 2019), digital technology is changing the way we think, create, communicate, learn, and work. Quebec's education system is an important incubator of change and innovation (Karsenti \& Bugmann, 2017). To a large extent, education and higher education are what will enable us to adapt, both now and in the future, and allow all members of society to have equal opportunity, educational success and the possibility of achieving their full potential.

Given the ubiquity of digital technologies in every area of our lives, Quebec's education system must not only adapt, but become an agent of change and innovation. To achieve this, all students, teachers and educational institutions must be able to seize the many opportunities afforded by digital technologies for teaching, learning, communication and creativity (see in particular Organisation for Economic Co-operation and Development, 2019). Major advances in digital technologies, namely robotics, automation and artificial intelligence (Karsenti, 2019), confirm the need to respond to the technological, ethical and social issues associated with innovations that are changing the way we live and work.

With this in mind, and with the desire for Quebec's education system to become a leader in the digital revolution (Deschamps de Paillette, 2019), the focus should be on digital skills and better educational practices in order to prepare learners for the challenges of tomorrow (Karsenti, 2018). That is why the Digital Action Plan for Education and Higher Education is rooted in the effective integration and optimal use of digital technologies to foster the success of all Quebecers, thereby promoting lifelong skills development and maintenance (MEES, 2018, p. 24). 
In concrete terms, this action plan translates into three major orientations. The first orientation involves contributing to the modernization and adaptation of the types of education and training offered, supporting the development of the digital skills of young people and adults, as well as promoting a digital culture. The second focuses on the optimal use of digital technologies by generating innovative practices, pooling resources and services, and developing a distance education offering adapted to the needs and realities of today's and future generations of learners. Finally, the third orientation involves monitoring learners' educational path, implementing adapted and flexible governance, and ensuring fair and safe access. These three orientations are broken down into 33 measures designed to give new impetus to the digital shift in the education system and to contribute actively to the development of Quebecers' digital skills (MEES, 2018).

These actions will be implemented over a five-year period, from 2018 to 2023, in close collaboration with education system stakeholders and partners. This action plan is intended to initiate an iterative and continuous process, since education must allow people to strengthen their ability to think and act in the face of rapidly evolving technologies (MEES, 2018).

This is the background against which this thematic issue of the International Journal of Technologies in Higher Education came to be. While our journal often presents scientific research backed by empirical data, its mission also includes highlighting experiences and practices that integrate digital technology, facilitating the sharing of papers on the pedagogical dimensions of the use and application of digital technology, as well as brief reviews.

Given the importance of digital technology in education, we thought it best to publish this thematic issue comprising a series of papers on a variety of initiatives and points of view related to the Digital Action Plan for Education and Higher Education. As we have both French- and English-language CEGEPs in Quebec, some papers are presented by their authors in both languages. CEGEP is an acronym for Collège d'enseignement général et professionnel, and is general and professional teaching college specific to Quebec. All pre-university and technical programs offered by CEGEPs are recognized by a government-sanctioned diploma.

The issue opens with a summary of the Digital Competency Framework, the latest governmental measures on the uses of technology in education. Bernard Tremblay, Director General of the Fédération des Cégeps, pens a paper on the importance of technology for teaching and learning in CEGEPS in which he describes how digital technologies have transformed CEGEPs. The third paper is authored by Stéphanie Carle of the Réseau des répondantes et répondants TIC des cégeps (REPTIC), in which she paints a picture of leading technopedagogical networks and organizations working with CEGEPs. Pierre-Paul Gros, science teacher at Champlain Regional College - an English-language CEGEP in Quebec - explains his vision of digital realities, inspired by his experiences as both a CEGEP teacher and university student. Chris Isaac Larnder and his colleagues from John Abbott College and Marianopolis College describe the different stages and results of an innovative project involving the use of digital technologies in teaching science at the CEGEP level. In the following paper, Vitrine technologie-éducation's ((http://vteducation.org) Pascale Blanc and her colleagues examine the importance of pooling digital educational resources (DER) and open educational resources (OER) in higher education. As for Denis Chabot of the Centre collégial de développement de matériel didactique (CCDMD), which produces printed, digital and online materials for teaching staff and students throughout the Quebec college system, his paper describes the different project development stages for answering the various needs of CEGEP learners and teachers. Normand Roy and his colleagues reflect on the issue of professional development at the post-secondary level in the era of digital 
technology. Jacques Cool and the team at Centre d'animation, de développement et de recherche en éducation pour le 21e siècle (CADRE21) bring to light a digital professional development strategy available online for all French-speaking teachers. The FADIO training model, an inspiring initiative for sharing distance learning expertise, is described by its coordinator, Mylène Simard of Cégep de Rimouski. With the help of colleagues, Cégep Saint-Laurent's Sirléia Rosa gives an account of developing a class on artificial intelligence in CEGEPs. Finally, Florent Michelot exposes the need for training skilled digital technology stakeholders, and the many challenges facing such a project.

\section{References}

Cristol, D. (2019). Former, se former et apprendre à l'ère numérique. ESF Sciences Humaines.

Deschamps de Paillette, T. (2019). Comprendre et vivre la révolution numérique : les enjeux sociétaux. Vie sociale, 2019/4(28), 51-64. https://doi.org/10.3917/vsoc.194.0051

Karsenti, T. (2018). Préparer les citoyens d'aujourd'hui à la société de l'information de demain : quels rôles pour les bibliothécaires et documentalistes? Documentation et bibliothèques, 64(4), 5-11. https://doi.org/10.7202/1061787ar

Karsenti, T. (2019). Artificial intelligence in education: The urgent need to prepare teachers for tomorrow's schools. Teachers and Teaching, 27(1), 105-111. https://doi.org/10.18162/fp.2019.166

Karsenti, T., \& Bugmann, J. (2017). Enseigner et apprendre avec le numérique. Presses de l'Université de Montréal.

Ministère de l'Éducation et de l'Enseignement supérieur. (2018). Plan d'action numérique en éducation et en enseignement supérieur. Les élèves et les étudiants : au cour de la révolution numérique. Gouvernement du Québec. http://education.gouv.qc.ca/...

Organisation for Economic Co-operation and Development (2019). OECD skills outlook 2019: Thriving in a digital world. http://oecd.org/... 